\title{
Air pollution and climate change effects on forest ecosystems: new evidence
}

\author{
R. Matyssek • M. Schaub - G. Wieser
}

Published online: 26 February 2010

(C) Springer-Verlag 2010

The following articles of this issue report on the outcome from an international conference entitled Air Pollution and Climate Change at Contrasting Altitude and Latitude held during September 7-12, 2008, in Murten/Switzerland under the auspices of the International Union of Forest Research Organisations (IUFRO). Key factors in air pollution and climate change, and in particular, the role of pollution in a changing environment were highlighted in numerous presentations. High anthropogenic nitrogen deposition was corroborated as a main driver both of effects mediated through elevated $\mathrm{CO}_{2}$ and enhanced ground-level ozone $\left(\mathrm{O}_{3}\right)$ exposure on forest trees and ecosystems. Awareness was directed to interacting effects of elevated $\mathrm{CO}_{2}$ and $\mathrm{O}_{3}$ levels (cf. Matyssek et al. 2010), as high $\mathrm{CO}_{2}$ has the capacity of ameliorating adverse $\mathrm{O}_{3}$ impact, whereas ozone may reduce the carbon sink strength, and hence, the buffering capacity of forest trees and ecosystems in relation to the increasing atmospheric $\mathrm{CO}_{2}$ level (cf. Sitch et al. 2007; Pretzsch et al. 2009). On such grounds, $\mathrm{O}_{3}$ has widely been recognized and emphasized during the conference as a major component of climate change at the global scale (cf. Fowler et al. 2008).

R. Matyssek ( $\square)$

Department of Ecology/Ecophysiology of Plants,

Technische Universität München, Am Hochanger 13,

85354 Freising, Germany

e-mail: matyssek@wzw.tum.de

M. Schaub

Swiss Federal Research Institute WSL, Zürcherstrasse 111, 8903 Birmensdorf, Switzerland

G. Wieser

Department of Alpine Timberline Ecophysiology,

Federal Office and Research Centre for Forests, Rennweg 1, 6020 Innsbruck, Austria
Being another outcome of progressive climatic change, drought requires continued research efforts, as it controlsvia stomatal regulation-the amounts of $\mathrm{O}_{3}$ and $\mathrm{CO}_{2}$ taken up by plants (cf. Paoletti and Grulke 2005; Köstner et al. 2008). Drought was recognized to bear the potential of protecting the vegetation from versus sensitizing it to $\mathrm{O}_{3}$ impact (cf. Matyssek et al. 2006). Recent evidence indicates aboveground $\mathrm{O}_{3}$ impact on forest trees to indirectly promote mitigation of the belowground carbon storage capacity of ecosystems (cf. Nikolova et al. 2009)—being crucial for the further progression of climate change.

There was consensus that, in particular, belowground effects of air pollution and climate change must attract further attention, as associated multi-factorial interactions have hardly been covered satisfactorily toward ascertaining process-based evidence. The risk of overlooking "the unknown unknown" remains a challenge in research and in prognosticating future tree and ecosystem performance. In particular, such a risk applies when considering biotic agents such as mycorrhizae and soil micro-organisms, as well as of competitors and host-parasite relationships. The plants' genotype per se was recognized as a fundamental determinant of tree and ecosystem responsiveness. Apart from the need for clarifying mechanistic grounds as pointed out above, concepts must be fostered toward concerted approaches in empirical research, long-term monitoring and modelling.

Apparent trends in the research conducted and evidence acquired during the past 20 years (Paoletti et al. 2010) reflect a shift in focus from

- a forest decline perspective to a holistic view on forest health,

- mono-factorial assessments and interpretations to interacting factorial impacts and associated antagonistic and synergistic responses, 
- effects solely on forest productivity to such on ecosystem services.

It was agreed that such trends are to be fostered in view of the challenges that will be imposed by future ecological scenarios. Some emphasis within the scope of the conference was directed to the differences in scenarios at contrasting altitude and latitude, highlighting current frontiers in evidence associated with the specificities of pollution and climate change, in particular, at high elevation sites and such in the tropical and sub-tropical climate zone.

A companion special issue of Environmental Pollution (Schaub et al. 2010) presents one bundle of representative publications from the conference (Braun et al. 2010; Grulke 2010; Matyssek et al. 2010; McNulty and Boggs 2010; Nunn et al. 2010; Paoletti et al. 2010; Savard 2010; Uddling et al. 2010). For this issue of EJFOR, additional six publications were selected, being briefly addressed in the following:

Risk assessment of ozone $\left(\mathrm{O}_{3}\right)$ impact on the carbon gain of representative Japanese conifers is the topic of Watanabe et al. (2009), basing their analysis on experimentation, $\mathrm{O}_{3}$ monitoring and vegetation surveys. Areas of high $\mathrm{O}_{3}$ induced reduction in carbon gain were not necessarily related to such of high $\mathrm{O}_{3}$ exposure, corroborating the weak indicative potential of exposure-based $\mathrm{O}_{3}$ risk indices. High tree productivity indicated enhanced $\mathrm{O}_{3}$ risk. In combination with the abundance of sensitive tree species, the regional $\mathrm{O}_{3}$ related decline in carbon gain becomes assessable.

Augustaitis et al. (2009) report on the seasonal variability of air pollution effects on pine under changing climate conditions. Enhanced levels and deposition of gaseous acidifying pollutants were found during the dormant period, as precipitation and temperature regimes during that time appeared to be crucial for crown condition. Expected climate scenarios are concluded to have the capacity of mitigating adverse effects of air pollutants and acid deposition on the crown condition of pine.

Thimonier et al. (2009) raise the question as to whether exceedance of the critical loads for nitrogen does alter nitrate leaching, tree nutritional status and crown condition. They found $\mathrm{N}$ deposition to be related to nitrate leaching below the rooting zone, to $\mathrm{N}$ nutrition of the canopy foliage and to the extent of defoliation. Crown defoliation of conifers tended to be negatively correlated with $\mathrm{N}$ concentrations in needles, whereas in many broadleaved stands, foliar $\mathrm{N}$ nutrition was in the optimum range. Respective correlations were absent in broadleaved trees between defoliation and foliar nutrition.

Multiple modeling of water chemistry in a mountain spruce catchment of the Silesian Beskid Mountains (Southern Poland) is demonstrated by Astel and Małek (2009) for a chronosequence of stands, while accounting for seasonal influences. Here, the washout of contaminants from the canopy alters the ion flux to the soil relative to the deposition through precipitation. In old, but not so in young stands, element levels were increased in the net through fall and accompanied by $\mathrm{pH}$ decline.

Schröder and Pesch (2009) report on long-term monitoring of metal accumulation in forests across Germany by means of the moss technique, being an approach of high spatial resolution of a broad spectrum of covered elements. Progressive decrease in metal bioaccumulation was found during 1990 through 2000, although this trend was reversed by 2005 , during the last year of the assessment period.

Aden et al. (2010) introduced a new web-based system for the management and analysis of forest monitoring data. Implementation was based on cartographic open-source software, enhancing the operational efficiency and visualization during data analysis.

The conference ended with the conviction that strengthened transcontinental collaboration is needed in jointly and consistently promoting concepts and methodologies in air pollution and climate change research. Such a demand exists, in particular, in view of new hot spots arising in Asia, South America and Africa.

\section{References}

Aden C, Schmidt G, Schröder W (2010) Data analyses with the WebGIS WaldIS. Eur J Forest Res (this volume)

Astel A, Małek S (2009) Multiple modelling of water chemistry flows assessed in a mountain spruce catchment. Eur J Forest Res. doi: 10.1007/s10342-009-0314-2 (this volume)

Augustaitis A, Augustaitiené I, Kliučius A, Pivoras G, Šopauskiene D, Girgždiené R (2009) The seasonal variability of air pollution effects on pine conditions under changing climates. Eur J Forest Res. doi:10.1007/s10342-009-0319-x (this volume)

Braun S, Thomas VFD, Quiring R, Flückiger W (2010) Does nitrogen deposition increase forest production? The role of phosphorus. Environ Pollut. doi:10.1016/j.envpol.2009.11.030

Fowler D, Amann M, Anderson R, Ashmore M, Cox P, Depledge M, Derwent D, Grennfelt P, Hewitt N, Hov O, Jenkin M, Kelly F, Liss P, Pilling M, Pyle J, Slingo J, Stefenson D (2008) Groundlevel ozone in the 21st century: future trends, impacts and policy implications. The Royal Society Policy Document, p 132

Grulke N (2010) Plasticity in physiological traits in conifers: implications for response to climate change in the western US. Environ Pollut. doi:10.1016/j.envpol.2009.12.010

Köstner B, Matyssek R, Heilmeier H, Clausnitzer F, Nunn AJ, Wieser $G$ (2008) Sap flow measurements as a basis for assessing tracegas exchange of trees. Flora 203:14-33

Matyssek R, Le Thiec D, Löw M, Dizengremel P, Nunn AJ, Häberle K-H (2006) Interaction between drought stress and $\mathrm{O}_{3}$ stress in forest trees. Plant Biol 8:11-17

Matyssek R, Karnosky DF, Wieser G, Percy K, Oksanen E, Grams TEE, Kubiske M, Hanke D, Pretzsch H (2010) Advances in understanding ozone impact on forest trees: messages from novel phytotron and free-air fumigation studies. Environ Pollut. doi: 10.1016/j.envpol.2009.11.033 
McNulty SG, Boggs JL (2010) A conceptual framework: redefining forest soil's critical acid loads under a changing climate. Environ Pollut. doi:10.1016/j.envpol.2009.11.028

Nikolova PS, Anderesen CP, Blaschke H, Matyssek R, Häberle KH (2009) Belowground effects of enhanced tropospheric ozone and drought in a beech/spruce forest (Fagus sylvatica L./Picea abies [L.] Karst). Environ Pollut doi:10.1016/j.envpol.2009.07.036

Nunn A, Cieslik S, Metzger U, Wieser G, Matyssek R (2010) Combining sap flow and eddy covariance approaches to derive stomatal and non-stomatal $\mathrm{O}_{3}$ fluxes in a forest stand. Environ Pollut. doi:10.1016/j.envpol.2009.11.034

Paoletti E, Grulke NE (2005) Does living in elevated $\mathrm{CO}_{2}$ ameliorate tree response to ozone? A review on stomatal responses. Environ Pollut 137:483-493

Paoletti E, Schaub M, Matyssek R, Wieser G, Augustaitis A, BastrupBirk AM, Bytnerowicz A, Günthardt-Goerg MS, Müller-Starck G, Serengil Y (2010) Advances of air pollution science: from forest decline to multiple-stress effects on forest ecosystem services. Environ Pollut. doi:10.1016/j.envpol.2009.11.023

Pretzsch H, Dieler J, Matyssek R, Wipfler P (2009) Tree and stand growth of mature Norway spruce and European beech under long-term ozone fumigation. Environ Pollut doi:10.1016/ j.envpol.2009.07.035

Savard MM (2010) Tree-ring stable isotopes and historical perspectives on pollution-an overview. Environ Pollut. doi:10.1016/ j.envpol.2009.11.031
Schaub M, Matyssek R, Wieser G (2010) Preface to the special issue of the IUFRO conference on air pollution and climate change effects on forest ecosystems. Environ Pollut. doi:10.1016/ j.envpol.2009.11.025

Schröder W, Pesch R (2009) Long-term monitoring of the metal accumulation in forests measured by use of the moss technique. Eur J Forest Res. doi:10.1007/s10342-009-0298-y (this volume)

Sitch S, Cox PM, Collins WJ, Huntingford C (2007) Indirect radiative forcing of climate change through ozone effects on the landcarbon sink. Nature 448:791-794

Thimonier A, Graf Pannatier E, Schmitt M, Waldner P, Walthert L, Schleppi P, Dobbertin M, Kräuchi N (2009) Does exceeding the critical loads for nitrogen alter nitrate leaching, the nutrient status of trees and their crown condition at swiss long-term forest ecosystem research (LWF) sites? Eur J Forest Res. doi: 10.1007/s10342-009-0328-9 (this volume)

Uddling J, Hogg AJ, Teclaw RM, Carroll MA, Ellsworth DS (2010) Stomatal uptake of $\mathrm{O}_{3}$ in aspen and aspen-birch forests under free-air $\mathrm{CO}_{2}$ and $\mathrm{O}_{3}$ enrichment. Environ Pollut. doi:10.1016/ j.envpol.2009.12.001

Watanabe M, Matsuo N, Yamaguchi M, Matsumura H, Kohno Y, Izuta T (2009) Risk assessment of ozone impact on the carbon absorption of Japanese representative conifers. Eur J Forest Res. doi:10.1007/s10342-009-0316-0 (this volume) 